\title{
A study on the effect of recent financial turmoil on performance of petrochemical industries: Evidence from Tehran Stock Exchange
}

\author{
Babak Eslami $^{\mathrm{a}^{*}}$, Mohammad Hemmati ${ }^{\mathrm{b}}$ and Fatemeh Namvar ${ }^{\mathrm{a}}$
}

${ }^{a}$ Department of Management and Accounting, Science and Research Semnan Branch, Islamic Azad University, Semnan, Iran ${ }^{b}$ Statistics Group, Department of Management, Semnan Branch, Islamic Azad University, Semnan, Iran

\section{CHRON I C L E}

\section{Article history:}

Received May 12, 2013

Received in revised format

12 August 2013

Accepted 14 August 2013

Available online

August 152013

Keywords:

Tehran Stock Exchange

Financial turmoil

Financial ratios

\section{A B S T R A C T}

\begin{abstract}
This paper presents a study to investigate the effect of world's financial turmoil on performance of petrochemical firms listed on Tehran Stock Exchange (TSE). The study designs a questionnaire in Likert scale and distributes it among 87 selected people from 250 existing experts who were active in TSE. The study considers four groups of questions associated with liquidity ratios, operating ratios, leverage and profitability ratios. The questions consider whether financial turmoil has influenced on these four groups of financial ratios or not and the results have been verified using t-student test. According to our survey, although financial turmoil does not seem to have any important impact on operating ratios in this sector, the chaos has influenced on other three financial ratios including liquidity, leverage and profitability ratios.
\end{abstract}

(C) 2013 Growing Science Ltd. All rights reserved.

\section{Introduction}

During the past two decades, world economy has experiences different financial crises such as September 11 incident (Borio, 2008; Park et al., 2008) or 2008 financial turmoil in United States banking system, which has motivated banking industry to monitor risk factors more closely. There are also various studies associated with the effects of financial crises on world's economy. Morshedian Rafiee (2012), for instance, presented a study to measure the risk of some private banks in Iran using Value at Risk (VaR) method. The proposed study collected the necessary information for the fiscal year of 2010 and analyzed them based on regression analysis. The study divided the financial data into two groups where the financial data of the first half of year was considered in the first group and the remaining data for the second half of year 2010 was taken into account in the second group. The implementation of VaR method indicated that financial risks increased during the

*Corresponding author. Tel: +989126037270

E-mail address: babakeslami20@yahoo.com (B. Eslami) 
time horizon and implemented linear regression method where independent variable was time, dependent variable was the financial risk, and the results confirmed their results.

Wagner and Winkler (2013) provided some empirical evidence on credit growth patterns of microfinance institutions in the early 2000 s. They reported that microfinance was vulnerable to financial turmoil and in the global financial crisis credit growth dropped, sharply. In addition, the crisis effect was more severe when institutions had been active in tapping domestic and international financial markets for funds and had operated in countries experiencing a severe post-crisis recession.

Chen and So (2002) investigated the relationship between exchange rate variability and the volatility of the returns of US multinationals using a sample of US multinationals with sales in the Asia-Pacific region. They tried to find out how exchange rate fluctuations around the 1997 Asian financial crisis had influenced the sensitivity of those firms to stock market risk. They reported that increases in exchange rate variability during the crisis were related to statistically significant increases in stock return volatility for the multinationals.

Tennant (2011) analyzed the results of a survey of 284 Jamaican businesses and detected the responses to the crisis that were viewed as most likely at that stage, and implemented logistic regression techniques to analyze the factors most likely to precipitate various kinds of responses. According to Klingenberg et al. (2013) operations management designs, schedules, and controls organizational processes could increase productivity by using different methods. White (2008) explained that while it is tempting to concentrate on new financial innovations in helping explain recent financial turmoil, more traditional causes should not be overlooked and we need to carefully monitor economic figures reported by financial houses. Chen and Alfaro (2010) discussed surviving the global financial crisis by investigating foreign direct investment and establishment performance.

Bahiti et al. (2011) investigated the effect of the latest financial crises on a bank-based financial system for a case study from Albania. Berger and Bouwman (2013) investigated how capital influences a bank's performance and how this impact differs across banking crises, market crises, and normal times, which happened in the United States over the past quarter century. They reported that capital helps small banks to increase their probability of survival and market share at all times and capital enhanced the performance of medium and large banks primarily during banking crises. Erkens et al. (2012) investigated corporate governance in the 2007-2008 financial crisis by looking into some evidences from financial institutions worldwide. Gros and Alcidi (2010) investigated the effect of the financial crisis on the real economy. Abdelbaki (2010) evaluated the effect of the global financial crisis on GCC countries. Sufian and Habibullah (2010) evaluated the impact of financial crisis on bank performance by looking into some empirical evidence from Indonesia.

\section{The proposed study}

The proposed study of this paper investigates the effect of world's financial turmoil on performance of petrochemical firms listed on Tehran Stock Exchange (TSE). There were 250 experts and analysts in the field of Iranian petrochemical industry. Therefore, we use the following formula to calculate the minimum number of sample size,

$$
n=\frac{N \times z_{\alpha / 2}^{2} \times p \times q}{\varepsilon^{2} \times(N-1)+z_{\alpha / 2}^{2} \times p \times q},
$$

where $N$ is the population size, $p=1-q$ represents the yes/no categories, $z_{\alpha / 2}$ is CDF of normal distribution and finally $\varepsilon$ is the error term. Since we have $p=0.5, z_{\alpha / 2}=1.96$ and $N=250$, the number of sample size is calculated as $n=87$. The study designs a questionnaire in Likert scale (Likert, 1932) and distributes it among 87 selected people from 250 existing experts who were active in TSE. The study considers four groups of questions associated with liquidity ratios, operating ratios, leverage 
and profitability ratios. The questions consider whether financial turmoil has influenced on these four groups of financial ratios or not and the results have been verified using t-student test.

The proposed study considers the following four hypotheses,

1. The world's financial turmoil influences positively on the performance of petrochemical firms listed on Tehran Stock Exchange (TSE) in terms of liquidity ratios.

2. The world's financial turmoil influences positively on the performance of petrochemical firms listed on Tehran Stock Exchange (TSE) in terms of operating ratios.

3. The world's financial turmoil influences positively on the performance of petrochemical firms listed on Tehran Stock Exchange (TSE) in terms of leverage ratios.

4. The world's financial turmoil influences positively on the performance of petrochemical firms listed on Tehran Stock Exchange (TSE) in terms of profitability ratios.

To examine these four hypotheses, the study has implemented t-student test. Table 1 demonstrates the results of our investigation.

\section{Table 1}

The summary of testing four hypotheses of the survey

\begin{tabular}{lllcll}
\hline Hypothesis & From & To & t-value & P-value & Result \\
\hline 1 & World's financial turmoil & Liquidity ratios & 0.63 & 0.016 & Confirmed \\
2 & World's financial turmoil & Operating ratios & 0.47 & 0.25 & Not Confirmed \\
3 & World's financial turmoil & Leverage ratios & 0.48 & 0.022 & Confirmed \\
4 & World's financial turmoil & Profitability ratios & 0.42 & 0.048 & Confirmed \\
\hline
\end{tabular}

As we can observe from the results of Table 1, although the recent US financial turmoil did not have any impact on operating ratios, the world financial crises has influenced other three ratios in petrochemical industry according to our survey.

\section{Conclusion}

In this paper, we have presented an empirical investigation to study the impact of recent financial crises on petrochemical industry whose shares were traded on Tehran Stock Exchange. The survey has designed a questionnaire in Likert scale, distributed among some experts in this industry and analyzed the results using t-student test. Based on the results of our survey, it is determined that liquidity and leverage ratios as well as profitability ratio have the capability to be impacted by world's financial turmoil. However, there was no evidence that world's financial turmoil could influence on operating ratios. In terms of liquidity ratio, despite the fact that the financial crises occurred four years after accomplishment of this survey but the sector is still suffering the bad consequences. In order to reduce the effect of such in future, the industry needs to increase current assets especially through cash or short investment.

\section{Acknowledgment}

The authors would like to thank all industry analysts for cordially participating in our survey. 


\section{References}

Abdelbaki, H. H. (2010). Assessing the impact of the global financial crisis on GCC countries. Journal of Business \& Economics Research (JBER), 8(2).

Bahiti, R., Shkurti, R., \& Babasuli, J. (2011). Impact of the latest financial crises on a bank-based financial system: Case of Albania. Romanian Economic Journal, 14(39), 3-23.

Berger, A. N., \& Bouwman, C. H. (2013). How does capital affect bank performance during financial crises?. Journal of Financial Economics, 109(1), 146-176

Borio, C. E. (2008). The financial turmoil of 2007-?: a preliminary assessment and some policy considerations (No. 251). Bank for International Settlements, Monetary and Economic Department.

Chen, C.C., \& So, R.W. (2002). Exchange rate variability and the riskiness of US multinational firms: evidence from the Asian financial turmoil. Journal of Multinational Financial Management, 12(45), 411-428.

Chen, M., \& Alfaro, L. (2010). Surviving the Global Financial Crisis: Foreign Direct Investment and Establishment Performance (No. 2010-17).

Chuang, I.Y., Chiu, Y.C., \& Wang, C.E. (2008). The performance of Asian airlines in the recent financial turmoil based on VaR and modified Sharpe ratio. Journal of Air Transport Management, 14(5). 257-262.

Erkens, D. H., Hung, M., \& Matos, P. (2012). Corporate governance in the 2007-2008 financial crisis: Evidence from financial institutions worldwide. Journal of Corporate Finance, 18(2), 389411.

Gros, D., \& Alcidi, C. (2010). The impact of the financial crisis on the real economy. Intereconomics, 45(1), 4-20.

Likert, R. (1932). A technique for the measurement of attitudes. Archives of Psychology, 140, 1-55.

Klingenberg, B., Timberlake, R., Geurts, T.G., \& Brown, R.J. (2013). The relationship of operational innovation and financial performance-A critical perspective. International Journal of Production Economics, 142(2), 317-323

Morshedian Rafiee, S., Houshmand Neghabi, Z., \& Feizollahei, A. (2012). Measuring the risk of an Iranian banking system using Value at Risk (VaR) Model. Management Science Letters, 2(7), 2673-2678.

Park, D., Jha, S., Jongwanich, J., Terada-Hagiwara, A., \& Sumulong, L. (2008).The US financial crisis, global financial turmoil, and developing Asia: is the era of high growth at an end? (Vol. 139). Mandaluyong: Asian Development Bank.

Sufian, F., \& Habibullah, M. S. (2010). Assessing the impact of financial crisis on bank performance: Empirical evidence from Indonesia. ASEAN Economic Bulletin, 27(3), 245-262.

Tennant, D. (2011). Factors impacting on whether and how businesses respond to early warning signs of financial and economic turmoil: Jamaican firms in the global crisis. Journal of Economics and Business, 63(5), 472-491.

Wagner, C., \& Winkler, A. (2013). The vulnerability of microfinance to financial turmoil: Evidence from the global financial crisis. World Development, 51, 71-90.

White, W. R. (2008). Past financial crises, the current financial turmoil, and the need for a new macrofinancial stability framework. Journal of Financial Stability,4(4), 307-312. 